\title{
Pilot trial of oral therapeutic HIV vaccine, V-1 Immunitor, on HIV and HIV/HCV patients in Russia
}

\author{
Aldar Bourinbaiar, Vladimir Orlovsky, Vichai Jirathitikal, Orapun Metadilogkul, Popov Dmitry \\ From $16^{\text {th }}$ International Symposium on HIV and Emerging Infectious Diseases \\ Marseille, France. 24-26 March 2010
}

\section{Background}

V-1 Immunitor (V1) is a therapeutic AIDS vaccine formulated as an oral pill comprising heat-inactivated HIV antigens derived from pooled blood of HIV-positive donors. Several studies carried out in Thailand have reported beneficial effects of V1 in AIDS patients including the increase in $\mathrm{CD} 4$ counts; decrease in viral load; body weight gain; improved clinical symptoms; and extended survival. The goal of our study was to substantiate these effects independently in another country.

\section{Methods}

We have tested V1 in seven randomly chosen HIVpositive patients at our regional AIDS Center. Five patients were therapy naïve patients but two have been receiving HAART during study period. Patients were administered one V1 pill per day for three months.

\section{Results}

No adverse effects due to V1 administration were observed at any time. The average increase in CD4-positive lymphocytes was 50 cells ( $22 \%$ or 228 vs $278 ; \mathrm{p}=$ $0.055)$; absolute CD8 cell counts increased by 29 ( $8 \%$ or 356 vs $385 ; \mathrm{p}=0.03$ ); plasma viral load as measured by PCR decreased in all patients ( $\mathrm{p}=0.018$ by Wilcoxon signed-rank test); the average weight gain was $4.6 \mathrm{~kg}$ ( $7.8 \%$ or 58.8 vs $64.4 ; \mathrm{p}=0.034$ ). Clinical symptoms as observed by physicians improved in all patients, including three patients co-infected with hepatitis $C$ virus. Patient-reported outcomes, i.e., appetite, energy, mood, and sense of well-being were also ameliorated.

\section{Discussion}

Despite small sample size, results of this study are statistically significant and support unequivocally the results of earlier trials in Thailand. Increase in CD4 counts and decrease in viral load can serve as immune correlates of vaccine efficacy in other AIDS vaccine clinical trials. Surprisingly V1 benefited HCV co-infection as well.

Published: 11 May 2010

Cite this article as: Bourinbaiar et al: Pilot trial of oral therapeutic HIV vaccine, V-1 Immunitor, on HIV and HIV/HCV patients in Russia. Retrovirology 2010 7(Suppl 1):P30.

Submit your next manuscript to BioMed Central and take full advantage of:

- Convenient online submission

- Thorough peer review

- No space constraints or color figure charges

- Immediate publication on acceptance

- Inclusion in PubMled, CAS, Scopus and Google Scholar

- Research which is freely available for redistribution 